\title{
Fatores ambientais associados ao consumo de frutas e hortaliças em população adulta do município de Viçosa - MG
}

Marina Gregório Machado Silva, Luciene Fátima Fernandes Almeida, Tiago de Melo Silva, Taiane Gonçalves Novaes, Giana Zarbato Longo, Milene Cristine Pessoa

\begin{abstract}
Resumo
A ingestão regular de frutas e hortaliças desempenha um papel significativo na saúde dos indivíduos, sendo que o ambiente alimentar é um fator importante que influencia tal consumo, uma vez que afeta a disponibilidade e acesso aos alimentos. Diante desse contexto, o estudo dessa relação subsidia políticas e programas voltados para a promoção da alimentação adequada e saudável. Analisar a associação entre a distribuição de estabelecimentos para a venda de alimentos e o consumo regular de frutas e hortaliças entre homens e mulheres adultos do município de Viçosa (MG). Estudo transversal de base populacional realizado com adultos de Viçosa entre 2012 e 2013. A amostragem foi realizada por conglomerados, sendo as unidades de primeiro estágio os setores censitários, e em seguida, os domicílios. Foram sorteados 30 setores censitários urbanos para o estudo dentre os 107 setores existentes em Viçosa, por meio de amostragem casual simples, sem reposição, utilizando tabelas de números aleatórios. $\mathrm{O}$ consumo de frutas e hortaliças foi obtido por meio de questionário que perguntava sobre a frequência de consumo destes alimentos. $\mathrm{O}$ consumo foi classificado como regular se maior ou igual a cinco vezes por semana e irregular se menor. Os dados dos estabelecimentos de venda de alimentos foram obtidos a partir da Classificação Nacional de Atividades Econômicas (CNAE), com avaliação das seguintes categorias: supermercados; minimercados; padarias; hortifrútis; restaurantes; bares; lanchonetes; açougues e peixarias; lojas de doces e ambulantes. Para verificar a associação entre o consumo regular e não regular de frutas e hortaliças e a distribuição do número de estabelecimentos que vendem alimentos, em um raio de $500 \mathrm{~m}$ da residência do indivíduo, utilizou-se o teste Qui-Quadrado de Pearson, adotando-se o nível de significância $\alpha=5 \%$. Foram avaliados 1229 indivíduos, sendo que 55,98\% eram mulheres e $73,72 \%$ consumiam regularmente frutas e hortaliças. Não houve diferença $(p=0,250)$ entre consumo regular de frutas e hortaliças entre homens $(72,09 \%)$ e mulheres $(75,00 \%)$. Para homens, houve associação entre consumo regular de frutas e hortaliças e número de estabelecimentos presentes em um raio de 500 metros de suas residências, para as seguintes categorias: supermercados $(\mathrm{p}<0,001)$; padarias $(\mathrm{p}<0,001)$; hortifrútis $(\mathrm{p}=0,004)$; restaurantes $(\mathrm{p}<0,001)$; bares $(\mathrm{p}=0,015)$; lanchonetes $(\mathrm{p}<0,001)$ e lojas de doces $(\mathrm{p}=0,004)$. Para mulheres, houve associação entre consumo regular de frutas e hortaliças e número de estabelecimentos presentes em um raio de 500 metros de suas residências, para as seguintes categorias: supermercados $(\mathrm{p}=0,014)$; minimercado $(p=0,026)$; padarias $(p=0,042)$ e restaurantes $(p=0,020)$. Conclui-se que houve associação entre a presença das diferentes categorias dos estabelecimentos que comercializam alimentos e o consumo regular e não regular de frutas e hortaliças. Notou-se maior número de associações para o sexo masculino, sugerindo que o ambiente exerce maior influência sobre o consumo de frutas e hortaliças dos homens.
\end{abstract}

Descritores: Ambiente Alimentar; Consumo de Alimentos; Adulto. 